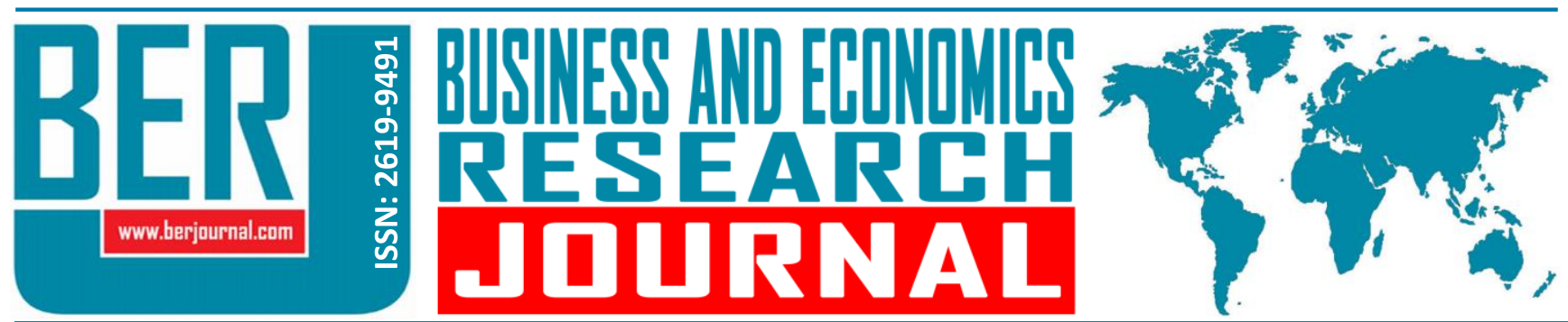

Business and Economics Research Journal Vol. 9, No. 4, 2018, pp. 811-823 doi: 10.20409/berj.2018.140

\title{
Düzey 1 Bölgelerinin İşsizliği Azaltmada Rekabet Gücüne Göre Siralanması
}

\author{
Inci Parlaktuna ${ }^{\mathrm{a}}$, Inci Saricicek ${ }^{\mathrm{b}}$
}

Öz: İssizliğin küresel ekonominin kronik bir meselesi olarak tanımlanması, ülkeleri işsizliği azaltmaya yönelik politikalara daha çok odaklanmalarına neden olmuştur. Türkiye'nin son dönemde ekonomik performansı arttırmış olmasına rağmen, işsizliği düşürmede yeterli düzeyde istihdam yaratamadığı görülmektedir. Bu sonuç ve yüksek işsizlik oranları bu alanda geliştirilen ve uygulanan politikaların istenilen başarıya ulaşamadığını gösterirken farklı bir bakış açısı ile yeniden ele alınması gerekliliğini de gündeme getirmektedir. Güçlü ekonomi yaratılabilmenin temel koşulu rekabet gücünü arttırmaktan geçer. Bölgesel rekabet gücü ise sürdürülebilir ve bölgenin göreli olarak yüksek faktör geliri ve faktör istihdamı yaratabilme yeteneği ile ilişkilidir. Bu bağlamda bölgenin sahip olduğu üretim faktörleri bölgenin rekabet gücünü belirlemede önemli role sahiptir. Işsizlik ise bölgelerin rekabet gücünü arttırma çabalarının önündeki engellerden biri olarak belirtilmektedir. Çalışmada Türkiye'nin iBBS Düzey 1'e göre sınıflandırılmış bölgelerin, rekabet gücünü belirleyen faktörleri dikkate alarak "çok ölçütlü karar verme" tekniğiyle sıralanması amaçlanmıştır. Rekabet gücünü belirleyen faktörler; imalat sanayisinde işgücü verimliliği, $A R-G E$ insan gücü sayısı, sanayideki ihracat oranı ve girişimci sayıları işsizliği azaltan ölçütler olarak alınmıştır. AR-GE insan gücü sayısı ve girişimci sayısı ölçütlerinin bölgelerin sıralamasını etkilediği sonucuna varılmıştır.

\section{Sorting of Level 1 Regions According to Competition Power in Unemployment Reduction}

\begin{abstract}
Unemployment, defined as a chronic issue of the global economy, causes countries to focus more on policies that will reduce unemployment. Although Turkey has increased her economic performance in last years, she cannot create sufficient employment to reduce unemployment. This result and high unemployment rates show that the developed and implemented policies can not reach the desired success. Thus, it is necessary to reconsider these policies from a different point of view. The basic condition for creating a strong economy is to increase the competitive power of the economy. On the other hand, regional competitiveness is related to sustainable and relatively higher ability to generate factor income and factor employment. In this context, production factors of the region play an important role in determining competitive power. Unemployment is considered to be one of the obstacles of the regions to increase competitive power. Aim of this study is to sort the Turkey's NUTS Level 1 regions with multiple criteria decision making technique by taking into account the competitiveness factors. Factors determining competitiveness; labor productivity in manufacturing industry, R\&D human power, industrial export rate, and number of entrepreneurs were taken as unemployment reducing factors. The results show that the R\&D human power and number of entrepreneurs affect the ranking of the regions.
\end{abstract}

Anahtar Sözcükler: İşsizlik, Bölgesel Rekabet, Bölgesel Kalkınma, Çok Ölçütlü Karar Verme, İmalat Sanayi

JEL: J08, R13, C38, L60

\begin{tabular}{|c|c|}
\hline Geliş & : 02 Mayıs 2018 \\
\hline Düzeltme & : 12 Haziran 2018 \\
\hline Kabul & : 20 Temmuz 2018 \\
\hline Tür & Araştırma \\
\hline
\end{tabular}

Keywords: Unemployment, Regional Competition, Regional Development, Multidisciplinary Decision Making, Manufacturing Industry

JEL: J08, R13, C38, L60

Received : 02 May 2018

Revised : 12 June 2018

Accepted : 20 July 2018

Type : Research

a Assoc. Prof., PhD., Eskisehir Osmangazi University, Faculty of Economics and Administrative Sciences, Department of Economics, Eskisehir, Turkiye, inci.orun60@gmail.com (ORCID ID- 0000-0002-1742-8607)

b Prof., PhD., Eskisehir Osmangazi University, Faculty of Engineering and Architecture, Department of Industrial Engineering, Eskişehir, Turkiye, incisa@gmail.com (ORCID ID -0000-0002-3528-7342) 


\section{Giriş}

Bugün işsizlik bir ekonomik sorunu olduğu kadar sosyal bir sorun olarak da tanımlanmaktadır. Ülkeler iktisadi değer yaratırken mevcut üretim kaynaklarını tam kapasite kullanamadıkları ve yeni istihdam alanları yaratamadıkları bundan dolayı eksik istihdam veya işsizlik gibi olumsuz ekonomik sonuçlarla karşı karşıya geldikleri rapor edilmektedir. Bu durum ülkelerin büyüme ve kalkınma düzeylerini olumsuz yönde etkilerken uzun süren durumlarda toplumsal sorunlar haline dönüşebilmektedir. Tüm dünya ülkelerinin işsizlik oranlarının artarak devam ettiği günümüzde, ülkelerin bu soruna çözüm önerileri aramaya odaklandığı belirtilmektedir. Krizlerin yarattığı olumsuz etkileri ortadan kaldırmak ve her yıl işgücü piyasasına katılan yüzlerce kişiye yeni istihdam alanları yaratmak için ülkeler istihdam yaratmaya yönelik politikaları geliştirmeye daha fazla yönelmektedirler. Türkiye'nin, büyümede yüksek performans sergilerken işsizliği azaltacak yeni istihdam alanları yaratma konusunda başarılı politikalar geliştiremediği gözlenmektedir.

Yaklaşık son 20 yılda hemen hemen her alanda yer bulan "rekabet" kavramı daha çok bölgesel, kentsel ve mekânsal çalışmalarla karşımıza çıkmaktadır. Bir ülkenin kalkınma düzeyinin ve dünya üzerindeki konumunun belirlenmesi ülkenin bölgelerinin sahip olduğu rekabet gücüyle doğrudan ilişkilidir. Ülkelerin rekabet gücünü geliştirmede ve arttırmada bölgelerin birer uygulama alanı olması, bölgelerin rekabet gücünün geliştirilmesinin önemini daha da arttırmaktadır. Bölgelerin rekabet gücünün o bölgede bulunan firmaların rekabet gücüyle kuvvetli bir ilişki içinde olduğu açıktır. Bu bağlamda bölgeler hem makro anlamda ülkenin rekabet gücünü etkileyen hem de mikro anlamda firmaların rekabet gücü tarafından etkilenen ve etkileyen önemli konuma sahiptir. Yüksek rekabet gücüne sahip bölgeler istihdam yaratma konusunda daha avantajlıdır. İşte tam burada ekonominin işsizliği azaltacak yeni istihdam alanları yaratması ile bölgenin rekabet edebilir güce sahip olması arasında karşılıklı ve kuvvetli bir ilişkinin varlığından söz edilebilir. Bölgelerin sahip olduğu kaynaklar (üretim faktörleri), bu kaynakların niteliği ve niceliği ve üretime dönüştürme becerisi (üretim teknolojisi) bölgenin rekabet gücünün belirleyicileridir. İşsizlik bölgenin sahip olduğu kaynağını yeterli düzeyde istihdam edemediğinin bir göstergesidir. Bu bağlamda işsizlik bölgelerin rekabet gücünü arttırmak ve bölgesel kalkınma çabalarının önündeki engellerden biri olarak dikkat çekilmesi gereken bir konudur. İşsizliği azaltmaya yönelik politikaların bölgesel rekabet gücünü arttırıcı politikaları kapsayacak şekilde geliştirilmesi bu açıdan önem arz etmektedir. Literatürde işsizlik konusunda birçok çalışma olmasına rağmen bölgelerin işsizliği etkileyen faktörler temelinde kıyaslandığı ile ilgili bir çalışma mevcut değildir. Çalışmada Türkiye'nin IBBS Düzey 1'e göre sınıflandırılmış bölgelerinin rekabet gücüne göre "çok ölçütlü karar verme" tekniğiyle sıralanması amaçlanmıştır. Bölgenin rekabet gücünün belirleyicileri işsizliği azaltıcı yönde etkileyen değişkenler dikkate alınarak belirlenmiştir.

Çalışmanın giriş bölümünde işsizlik temelinde bölgesel rekabet gücünün önemi açıklanmıştır. İkinci bölümde bölgesel rekabet gücü ile işsizlik ilişkisi ele alınmış ve üçüncü bölümde konu ile ilgili literatüre yer verilmiştir. Dördüncü bölümde Türkiye'nin İBBS Düzey 1'e göre sınıflandırılmış bölgeleri belirlenen ölçütler temelinde analiz edilmiştir. Beşinci bölümde Düzey 1'e göre sınıflandırılmış bölgelerin kıyaslanmasında kullanılan yöntem ve bulgulara yer verilmiş ve altıncı bölümde sonuçlar ortaya konmuştur.

\section{2. İ̧sizlik ve Bölgesel Rekabet Gücü}

İktisat literatüründe işsizlikle büyüme ve işsizlikle enflasyon ilişkilerini inceleyen sırasıyla Okun yasası ve Phillips eğrisi teorileri mevcuttur. İşsizliğin hem ekonomik hem de sosyal etkileriyle karmaşık yapıya sahip olan çok yönlü bir problem olması, işsizliği tek başına ele almak veya büyüme ya da enflasyonla ilişkilendirerek politikalar geliştirmek hem ekonomik bir politika yanlışı olarak karşımıza çıkmakta hem de çalışmalar bu tür politikaların işsizliği düşürmede etkili olmadı̆̆ını vurgulamaktadır (Kanca, 2012).

İşizlik sorununu verimlilik ve ücret ile sıkı ilişkinin olduğunu gösteren makroekonomik çerçeveli başka teoriler de mevcuttur. Bu teorilere göre işsizlik ile verimlilik ve ücret arasında kuvvetli bir ilişkinin olmasının yanı sıra birbirlerini de etkiledikleri kabul edilmektedir. Burada bahsedilen işgücü verimliliğidir ve toplam çıktının toplam işgücüne oranlanmasıyla hesaplanmaktadır (Wakeford, 2004:110). İşgücü verimliliğinin artması aynı işi daha az kişi yapması anlamına geldiğinden aslında işsizliği arttırdığı şeklinde değerlendirilebilir. Ancak işgücü verimliliğinin artması aynı zamanda kaynakların verimli kullanılmasıyla 
firmaların karlarını arttırmakta ve buna bağıı olarak firmaların yatırımlarının artmasına neden olmaktadır. Böylece artan yatırımlar firmaların işgücü talebini arttırarak işsizliği azaltmaktadır. Ancak işsizlik ve verimlilik arasında nedenselliğin hangi yöne doğru olacağı çok net değildir. Hatta yüksek işsizliğin işten çıkarılma beklentisinden dolayı verimliliği arttırdığı da söylenebilir (Kanca, 2012). Güçlü bir ekonomi için rekabet gücünü arttırmak hedeflenirken aynı zamanda üretim faktörlerinde yüksek bir verimlilik de hedeflenmektedir. Bölgeler üretim faktör verimliliğini arttırırsa bölgenin rekabet gücü ve yeni iş alanlarıyla istihdam oranı artar.

Ülkenin rekabet gücünü arttırma çabası ekonomi politikalarının temel amaçlarının içerisinde yer verilmelidir. Otoritenin bu amaçlı bir politikayı hedeflemesi güçlü bir ekonomiye sahip olabileceği anlamına gelmektedir. Diğer bir ifade ile güçlü ekonominin yaratılabilmesinin esas koşulu rekabet gücünü arttırmaktan geçmektedir. Ülkelerin yeni dünya düzeninde rekabet edebilme ve dünya konumunda yerini koruyabilme çabaları politikacıları politikalarını geliştirmelerinde farklı bir bakış açısına yöneltmiştir. Burada dikkat edilmesi gereken nokta ülke düzeyinde rekabet gücü ile bölgelerin ve firmaların düzeyinde rekabet gücünün farklılık göstermesidir. Ancak bugün ülkenin rekabet edebilirliği bölgesel temellerinin sağlamlaştırımasına ve bölgelerin tamamının rekabet edilebilirliklerinin arttırılmasına bağlıdır. Bölgesel rekabet gücü arttırılırsa ulusal düzeyde rekabet gücü ve refahı artacaktır (Kara, 2008:14).

Bölgesel rekabet gücünün tanımı ve ölçümü konusunda tam bir görüş birliğine varılmamış olsa dahi birçok tanım yapılmıştır. Avrupa Birliği'nin Bölgeler Üstündeki Altıncı Periyodik Raporuna (1999) göre bölgesel rekabet edilebilirlik "sürdürülebilir ve nispi olarak yüksek faktör geliri ve faktör istihdam düzeyi yaratabilme becerisi" olarak tanımlanmıştır (European Commission, 1999). Bölgeler iktisadi faaliyetleri geliştirmek, iktisadi faaliyetleri kendi bölgesine çekmek ve sürdürülebilmek amacıyla rekabet ederler. Rekabet edebilme bölgenin fırsatlarını değerlendirme ve istihdam yaratabilme kabiliyetini güçlendirmektedir. Bu bağlamda bölgesel düzeyde rekabet gücü kazanma bölgenin zayıf ve güçlü yönlerini ortaya koyan bir yapıyla ilişkilidir.

Yeni bakış açısı bölgelerin sahip oldukları vasıflı insan gücü, teknik bilgi birikimi ve sosyal kurumsal alt yapı gibi faktörlerin sermaye ve emek girdilerinin verimliliğini arttıracağını, verimlilikteki artışın üretim ve rekabet gücünü arttıracağı bakışını ifade etmektedir. Bölgenin avantajını ya da rekabet gücünü belirleme konusunda en kapsamlı çalışma M. E. Porter tarafından yapılmıştır ve modelin ana teması yenilik ve bilgilerin iyileştirilmesine dayanmaktadır. Böylece rekabet gücünü belirleyen faktörlerin birbiriyle etkileşim hızı ve etkinliği bölgenin rekabet edebilme gücünü gösteren faktörleri ortaya çıkarmaktadır (Webster ve Muller, 2000).

Bölgelerin rekabet gücü bölgenin ekonomik yapısı, fiziksel çevresi, sosyal yapısı ve beşeri sermaye yapısı gibi her birini veya tümünü dikkate alan faktörler tarafından belirlenebilir. Bölgelerin rekabet gücünü belirleyen faktörlerle bir sınıflama yapılacaksa ekonomik faktörler ve stratejik faktörler olarak iki alt başlıkta toplanabilir (Malecki, 2001). Ekonomik faktörler bölgedeki üretim faktörleri ve düzeyi, üretim teknolojisi, beşeri sermaye, bölgenin alt yapısı, talep koşulları ve ekonominin sektör yapısı, işgücü yapısı gibi değişkenlerden oluşmaktadır. Stratejik faktörler ise firmaların sektörlerle olan ilişkileri, idari etkinliği, kamu sektörü ile işbirliği, bölgenin kalkınma stratejisi, kamu ve özel kesimin ilişki düzeyleri, kurumsal yapı gibi değişkenler olarak sıralanabilir. Bu iki faktörü birbirinden ayıran en temel özellik ekonomik faktörler gözlemlenirken stratejik faktörlerin gözlemlenemediğidir. Bu nedenle analizlerde ekonomik faktörün tercih edilmesi objektif ve elde edilebilirliği kolay olmasına dayanmaktadır.

Bölgenin rekabet gücünü belirleyen ekonomik faktörler iki farklı açıdan ele alınabilir. Birincisi çok genel amaçlı üretim yapmak için kullanılan toprak, maden gibi doğal kaynaklar ve vasıfsız veya orta vasıfı işgücü gibi temel üretim girdi değişkenleridir. İkincisi belirli hedefler doğrultusunda geliştirilmiş vasıflı işgücü, modern alt yapı, ileri teknoloji gibi gelişmiş üretim girdilerinden oluşmaktadır. Küreselleşmenin ve yapılan düzenlemelerin üretim faktörlerinin ticaretini serbest hale getirmesi, temel üretim girdi değişkenlerine sahip olmanın avantajını ortadan kaldırmış ve temel üretim girdileri yerini gelişmiş üretim girdilerine bırakmıştır. Gelişmiş olan üretim girdilerinin yeni ürünlerin (patentli ürünlerin) üretilmesinde, yeni üretim tekniklerinin ve teknolojinin geliştirilmesinde önemli katkıları vardır. Bu katkılar gelişmiş olan üretim girdilerinin üretime 
dönüştürme verimliliğine dayanmakta ve rekabet gücünün artmasıyla ve en önemlisi de sürdürülebilmesiyle birlikte gerçekleşmektedir. Üretim girdilerinin verimlilik artışı girdi ile üretim arasındaki olumlu ilişkinin sürekli olmasını sağlamaktadır (Gereffi, 1999:22).

\section{Literatürdeki Çalışmalar}

Türkiye'de dâhil olmak üzere birçok ülke için işsizliğin nedenlerini belirleyen çok sayıda mevcut çalışma olmasına rağmen bölgeleri dikkate alan araştırmalar ne yazık ki az sayıdadır. Bu çalışmayı destekleyen literatür çalışmaları iki grup altında incelenmiştir. Birinci grupta bölgelerin rekabet edebilirliğini dikkate alan çalışmaları, ikinci grupta Türkiye'nin bölgelerini dikkate alarak yapılan çalışmaları kapsamaktadır.

Birinci Grup Çalışmalar; Bu gruptaki çalışmalar bölgelerin rekabet edebilirliği ile ilgili çalışmalardır. Huovari, Kangazharharju ve Alanen (2001) yaptıkları çalışmada bölgelerin sahip olduğu üretim faktörlerinin bölgenin rekabet gücünü belirlemede önemli olduğunu ve eğer bölge sahip olduğu üretim faktörleri açısından zengin ise bölgenin rekabet edebilme kapasitesinin yüksek olduğunu vurgulamaktadır. Camagni (2002), bölgelerin rekabet edebilmesinin ancak mutlak üstünlükle sağlanacağını belirtmiştir. Ayaş (2002)'deki çalışmasında verimlilik ile rekabet gücü ilişkisine yer vererek verimlilik artışlarının bölgesel rekabet gücünün temel kaynağı olduğunu ve verimliliğin yığılma ekonomileriyle yakın ilişkisi olduğunu anlatmıştır. Beceren (2004) yılında yapmış olduğu çalışmasında rekabet gücünün ölçülmesinin önemini vurgulayarak bölgesel rekabet gücü ile istihdam yaratma imkânları arasında doğrudan pozitif bir ilişkili olduğu sonucuna varmıştır. Dabson (2005) bölgesel rekabet edebilirlikte teknoloji faktörünün ön plana çıkartılması gerekliliğine vurgu yaparak teknoloji kavramına rekabet edilebilirlik kavramının içinde yer vermiştir. Kara (2008) çalışmasında belli bir mekândaki üretim faktörlerinin konumu ve kullanımının iktisadi birimlerin rekabet edebilirliklerini etkilemekte olup olmadığını araştırmıştır. Albayrak ve Erkut (2010)'deki çalışmasında bölgesel kalkınma politikalarının bölgenin rekabet gücünü arttırmaya yönelik geliştirilmesinin bölgelerin rekabet edebilirliğinin önemini arttırdığını belirtmiştir. Kerimoğlu ve Sözer (2017) bölgesel rekabet gücünü belirleyen değişkenleri dört ana başlık altında toplamıştır. Bu dört değişkenden özel sermaye kaynaklarını bünyesinde barındırabilen, yenilikçi yapısı gelişmiş ve insan sermayesi bakımından zengin olan bölgelerin rekabet edebilme açısından önemli avantaja sahip olduğunu vurgulamıştır. Bölgesel rekabet edebilme, emek gücünü ve ekonomik faaliyetleri bölgeye çekme becerisi ve bölgenin ekonomik faaliyetlerini arttırma kapasitesi ile açıklamıştır (Kitson vd., 2004).

İkinci Grup Çalışmalar; İşgücü piyasalarını bölgesel kalkınma ve eşitsizlik açısından ele almaktadır. Bölgelerarası farklılıklar ya da eşitsizliklerin bölgenin rekabet gücü ile yakın ilişkisi olması bu konulardaki çalışmaların incelenmesini gerektirmiştir. Cai, Wang ve Du (2002) çalışmalarında Çin bölgesini araştırmışlardır. İşgücü piyasasındaki bozulmaların Çin'in bölgesel ekonomik büyüme ve farklılıklara neden olduğuna dair bulgular elde etmişlerdir. Hükümetin yerel işçilerin iş güvencelerini koruyan, işgücü hareketliliğini kısıtlayan politikalar ile bölgelerin birbirlerine yakınsayacağını vurgulamıştır. Yüceol (2007) yaptığı çalışmasında Türkiye ỉBBS Düzey 2 bazında bölgesel işgücü hareketliliği ile işsizlik arasındaki bağlantıyı belirleyerek bölgeler arasındaki işsizlik oranları farklılığını azaltmada bir etkisinin olup olmadığını araştırmıştır. Enflo ve Roses (2015) çalışmalarında bölgesel gelir farklılıklarının uzun dönemde azaltılmasını üç dönemde incelemiş ve arkasında pazarların genişlemesi, göçlerin ve verimlilik farklarının azaltılması, kurumsal düzenlemeler gibi yapısal değişimler olduğunu teknolojik güçlerin daha az rol oynadığını belirtmiştir. Akyelken (2015), çalışmasının mantığı ekonomik kalkınmayı eşitlik konusunu sosyal ve kültürel konular açısında ele alarak ulaşım alt yapısının etkilerini incelemektir. Çalışmasında cinsiyet farklılıklarının ve sosyokültürel faktörlerin Türkiye'deki istihdamın üzerindeki rollerini göz önüne alarak, eğitim ile ücretli istihdam ve ulaştırma altyapısı arasındaki etkileşimin etkilerini göstermeye çalışmıştır. Öztürk (2018), çalışmasında Türkiye'nin bölgelerarası farklılı̆ını sosyo-ekonomik değişkenler ve bölgelerin dinamiklerini dikkate alarak işgücüne katılım oranları temelinde analiz etmiş ve işgücüne katılımda eğitim düzeyinin, bağımlılık oranının önemli olduğunu vurgulamıştır. Aydın (2017), çalışmasında Türkiye iBBBS Düzey 2 temelinde bölgesel olarak enflasyon ve büyüme arasındaki ilişkiyi panel yumuşak geçişli regresyon yaklaşımı kullanarak incelemiş ve enflasyonun eşik değerinin üstündeyken büyüme oranı artışının işsizliği arttırdığı, altındayken azalttığı sonucuna varmıştır. 
Parlaktuna ve Sarıçiçek (2010), yapmış oldukları çalışmada bölgelerin sosyo-ekonomik gelişmişlik açısından farklıııklarının nedenini bölgelerin kadın işgücüne katılımını sağlayan ve çalışmada potansiyel güç olarak tanımlanan makroekonomik ve sosyal faktörlerin (ölçütlerin) belirlenmesini ve Türkiye'nin ỉBBS Düzey 1'e göre sınıflandırılmış bölgelerin potansiyel açısından sıralanmasını amaçlamıştır. Toplumsal cinsiyet eşitliği çerçevesinde yapılan bir çalışma Lechman ve Kaur (2015) tarafından 1990-2012 dönemi ve 162 ülke için yapılmıştır. Bu çalışmada kadın işgücü ve ekonomik büyüme arasındaki ilişkiye yeni bir bakış açısı getirilerek literatüre katkıda bulunulmuştur.

\section{Türkiye'nin Düzey 1'e Göre Sınıflandırılmış Bölgelerinin Ele Alınan Ölçütler Temelinde Analizi}

Çalışmada Türkiye'nin IBBS Düzey 1'e göre sınıflandırılmış bölgelerinin rekabet gücüne göre sıralanması amaçlanmıştır. Bölgelerin rekabet gücünün belirleyicileri bölgenin istihdam yaratma potansiyeli olan değişkenler çerçevesinde belirlenmiştir. Sıralama "çok ölçütlü karar verme" modeli kullanılarak yapılmıştır. İstihdam yaratma potansiyeli olan değişkenler bu çalışmada kullanılan modelde "ölçütler" olarak adlandırılmaktadır.

\subsection{Modelde Dikkate Alınan Ölçütler}

Çalışmada kullanılan ölçütler, bölgede istihdamı arttırma veya işsizliği düşürme etkisi olan ölçütler arasından seçilmiştir. Bu ölçütler sırasıyla imalat sanayisinde işgücü verimliliği, AR-GE insan gücü, sanayideki ihraca oranı, girişimci sayısı olarak adlandırılmıştır. Ölçütlere ilişkin veriler Tüik bölgesel istatistik veri tabanından alınmıştır.

Ölçüt 1: İmalat Sanayisinde İşgücü Verimliliği; 2014 yılında bölgedeki imalat sanayisinde istihdam başına düşen imalat sanayi üretim düzeyidir (Bölgenin imalat sanayisindeki üretim miktarının bölgenin imalat sanayisinde istihdam edilenlerin sayısına bölünerek hesaplanmıştır).

Ölçüt 1 bölgedeki imalat sanayisinde istihdam edilenlerin birim başına ürettikleri imalat sanayisinin üretim düzeyidir. Diğer bir ifade ile imalat sanayisinin işgücü verimliliğini göstermektedir. Verimlilik artışları üretim girdileri başına üretilen çıktı değerini arttırma yeteneğini göstermektedir (Lee ve Hyoungso, 1998:24). İmalat sanayisi ekonominin GSYiH'nin büyüme hızının itici gücüdür. İmalat sanayisi yeni teknolojilerin geliştirilmesi ve diğer sektörlere yayılmasında kritik bir konuma sahiptir ve emek üretkenliğinin artmasını da doğrudan etkiler. İşgücü verimliliğinin artışı kişi başı gelir düzeyinin artması, artan gelirin sanayi mallarına olan talebi artırarak sanayi yatırımının artması, diğer sektörlerde canlanma etkisi yaratması ve ihracatın artması gibi kanallar açan önemli bir değişkendir. İmalat sanayisinde işgücü talebinin büyüme hızına olan esnekliğinin diğer sektörlere göre daha yüksek olması, verimlilikteki bu değişimin GSYiH'yi artma yönünde ivme kazandırmaktadır (Kaldor, 1975). İşgücü verimliliğindeki artışın sektörlere getirdiği bir dizi olumlu etki paralel olarak istihdamda da gerçekleşmektedir. Kısaca imalat sanayisindeki verimlilik artışı hem sektörde istihdam artışına hem de diğer sektörlerde istihdam artışına sebep olur. Aynı zamanda sektörlerin karlılık düzeylerini artırarak yeni iş yerlerinin ve istihdam alanlarının açılmasına yol açmaktadır.

Ölçüt 2: AR-GE İnsan Gücü; 2016 yılında bölgedeki AR-GE insan gücü sayısının toplam istihdam içindeki oranıdır (bölgenin AR-GE insan gücü sayısı bölgenin toplam istihdam edilenlerin sayısına bölünerek hesaplanmıştır).

Ölçüt 2 bölgedeki AR-GE insan gücü sayısının toplam istihdam içindeki oranını göstermektedir. Ekonomide AR-GE ve teknolojik yenilikler ekonomideki büyümenin temel kaynakları olarak tanımlanmaktadır. Eğer ülke küresel üretim zincirinde yer alıyorsa o ülkenin AR-GE ve yenilikçi katkılarının oldukça yüksek olduğu ve o alanlarda uzmanlaştığı belirtilmektedir. Bu durum gelişmiş ülkeler için söylenirken, gelişmekte olan ülkeler için montaj sektöründe uzmanlaştıklarını ifade edebilir. Norda ve Kim (2013) çalışmasında montaj sanayisinde uzmanlaşmanın gelişmekte olan ülkelerin hizmet sektörlerinin belirlenmesinde önemli bir rol oynadığını, bu nedenle hizmet sektörünün tek başına büyüme üzerinde etkisinin olamayacağını vurgulamaktadır. Hizmet sektörünün pozitif etkisinin ancak sanayi sektörü tarafından belirleneceğini ileri sürmüştür. Onlar lojistik, telekomünikasyon ve finansal hizmetler gibi sektörlerin büyümesinin sanayi sektörünün performansı üzerinde önemli pozitif etki yarattığını, bu nedenle yüksek 
teknolojili sanayi sektöründe üretilen ürünlerin hizmet sektörüne daha fazla ihtiyaç duyduğunu vurgulamaktadır. Çalışmada seçilen ölçüt 2'nin yüksek değere sahip olması bölgedeki istihdam yaratma ve sürdürebilme potansiyelinin yüksek olduğunu göstermektedir.

Ölçüt 3: Sanayideki ihracat Oranı; 2015 yılında bölgedeki imalat sanayisinde yapılan ihracatın toplam ihracat içindeki oranı (bölgenin sanayi ihracatının bölgenin toplam ihracatına bölünerek hesaplanmıştır).

Ölçüt 3 bölgedeki imalat sanayinde yapılan ihracatın toplam ihracat içindeki oranıdır. Uluslararası ticaretin büyük bir kısmının sanayi ürünlerinden oluşması rekabet eden firmanın, bölgenin veya ülkenin rekabet edebilirliğinin bir göstergesidir. Sanayi ürünlerinin ihracatının artışı bölgenin GSYIH'sini arttırırken, firmaların karlılığını arttırarak yeni iş alanlarının ve rekabet gücünün artmasına yol açmaktadır.

Ölçüt 4: Girişimci Sayısı; 2016 yılında iş kayıtlarına göre bölgelerdeki girişimcilerin sayılarını göstermektedir.

Ölçüt 4 bölgenin girişimci sayısındaki artışlar istihdam imkânlarını doğrudan ve pozitif etkilemektedir. Bölge sıralamasında girişimci sayısındaki artışlar etkili bir gösterge olarak düşünülmüştür.

Seçilen dört ölçüt sadece istihdam yaratma potansiyelini değil aynı zamanda sürdürülebilir olma potansiyelini de kapsamaktadır

\subsection{Düzey 1 Bölgelerinin Mevcut Durumu}

İssizlik, ekonomik ve sosyal yapılardaki değişimlere, küreselleşmeye ve yaşanan krizlere bağlı olarak 1980 'li yıllardan başlayan ve düzeyi gittikçe artan en temel problemlerden biri haline gelmiştir. Şekil 1'de Türkiye'nin Düzey 1'e göre sınıflandırılmış bölgelerinin işsizlik oranları gösterilmiştir.

Şekil 1. Türkiye’nin İBBS Düzey 1 Sınıflandırılmış Bölgelerin İşsizlik Oranları (2016)

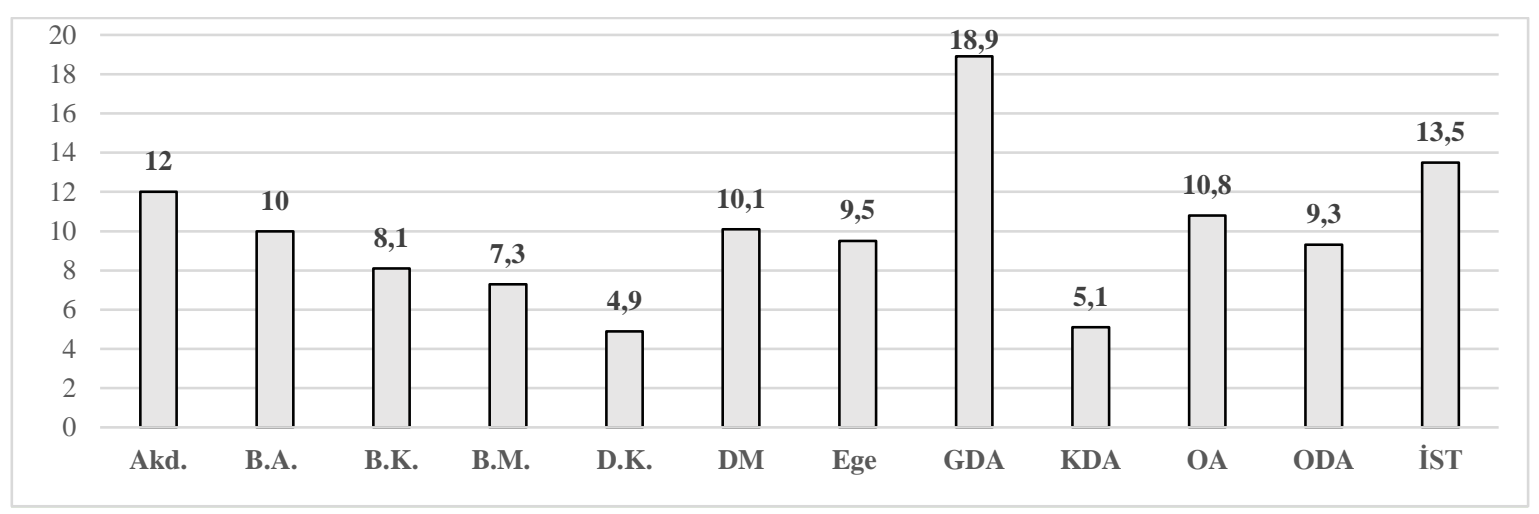

Kaynak: TÜiK Bölgesel İstatistikler 2016

Şekil 1'de görüldüğü gibi işsizlik oranları bölgelere göre farklılık göstermektedir. İşsizlik oranı en yüksek bölge \%18,9 ile Güneydoğu Anadolu bölgesidir. Onu \%13,5 ile İstanbul bölgesi izlemektedir. En düşük işsizlik oranı \%4,9 ile Doğu Karadeniz Bölgesindedir. Türkiye'deki işsizlik sorunu, sanayileşmede istenilen düzeye gelinememesi, genç nüfus oranının hızlı artışı ve istihdamı sağlayacak yatırımların yeterli düzeyde olmaması, işgücü piyasasının yapısı ve artan hareketliliği, politik şartlar ve ekonomik krizler gibi yapısal özelliklere sahiptir (Kanca, 2012). Bu yapısal sorun Türkiye'de istihdam yaratma hızının işgücü arzının artma hızından küçük olarak gerçekleşmesiyle neticelenmektedir. Eğer işsizliği azaltıcı önlemler alınmaz ise ekonomik sorunlar artarak daha ciddi boyutlara ulaşacağı söylenebilir. İşsizlik önemli bir üretim faktörünün atıl bırakılarak ülkelerin potansiyel düzeylerinin altında üretim yapmalarına sebep olmaktadır. Şekil 1 incelendiğinde, Türkiye'nin işsizliği azaltmaya yönelik politikalarda başarı sağlayamadığını söylemek yanlış olmayacaktır. 
Türkiye'nin bir yandan sanayileşmesi bir yandan kırsal kesimden kent kesimine doğru göç artışının olması tarım sektörünün GSYiH içindeki payının küçülmesi sonucunu getirmiştir. Aslında Türkiye'deki işsizlik sorunu ekonomik yapının tarım sektöründen hizmet ve sanayi sektörüne doğru dönüşümden kaynaklanmaktadır. Gelişmişte olan ülkelerde tarım sektöründe çalışanlar doğrudan hizmet sektörüne geçmektedir. Buradaki sorun tarımdan doğrudan hizmet sektörüne geçenlerin hizmet sektörünün niteliklerine uygun olmamasıdır. Bu geçiş sonucu maalesef hem tarım sektörü daralmakta hem de hizmet sektörü genişlememektedir (Özdemir, Ersöz ve Sarıoğlu, 2006:92; Güney, 2009: 140). Şekil 2'de Türkiye'nin Düzey 1'e göre sınıflandırılmış bölgelerin GSYiH'nin faaliyet kollarına göre oranları gösterilmektedir.

Şekil 2. Türkiye'nin Düzey 1'e Göre Sınıflandırılmış Bölgelerin GSYiH'nin Faaliyet Kollarına Göre Oranları

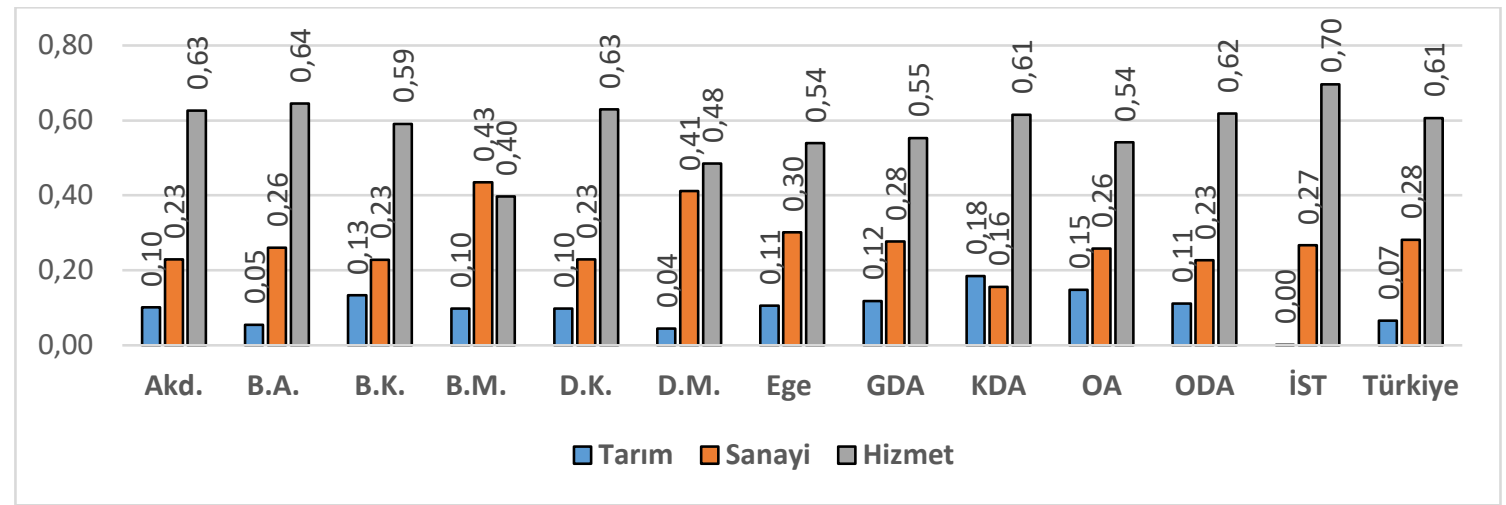

Kaynak: TÜiK: Bölgesel İstatistikler 2016

Türkiye'nin GSYiH'sinin \%61'i hizmet, \%28'i sanayi, \%0,07'si tarım sektöründen elde edilmektedir. Şekil 2' de görüldüğü gibi Batı Marmara bölgesi dışında diğer bölgelerde faaliyet sıralaması Türkiye'nin faaliyet sıralamasına benzerdir. Batı Marmara bölgesi, Doğu Marmara ve Ege bölgeleri sanayi üretiminde ilk sıralarda yer almaktadır. Hizmet üretiminde sırasıyla İstanbul, Batı Anadolu, Akdeniz, Doğu Karadeniz, Ortadoğu Anadolu bölgeleri gelmektedir. Şekil 3'te Türkiye'nin Düzey 1'e göre sınıflandııılmış bölgelerinin GSYiH'sının faaliyet kollarına göre istihdam oranları gösterilmektedir.

Şekil 3. Türkiye'nin Düzey 1'e göre sınıflandırılmış bölgelerinin GSYiH'sının faaliyet kollarına göre istihdam oranları (2016)

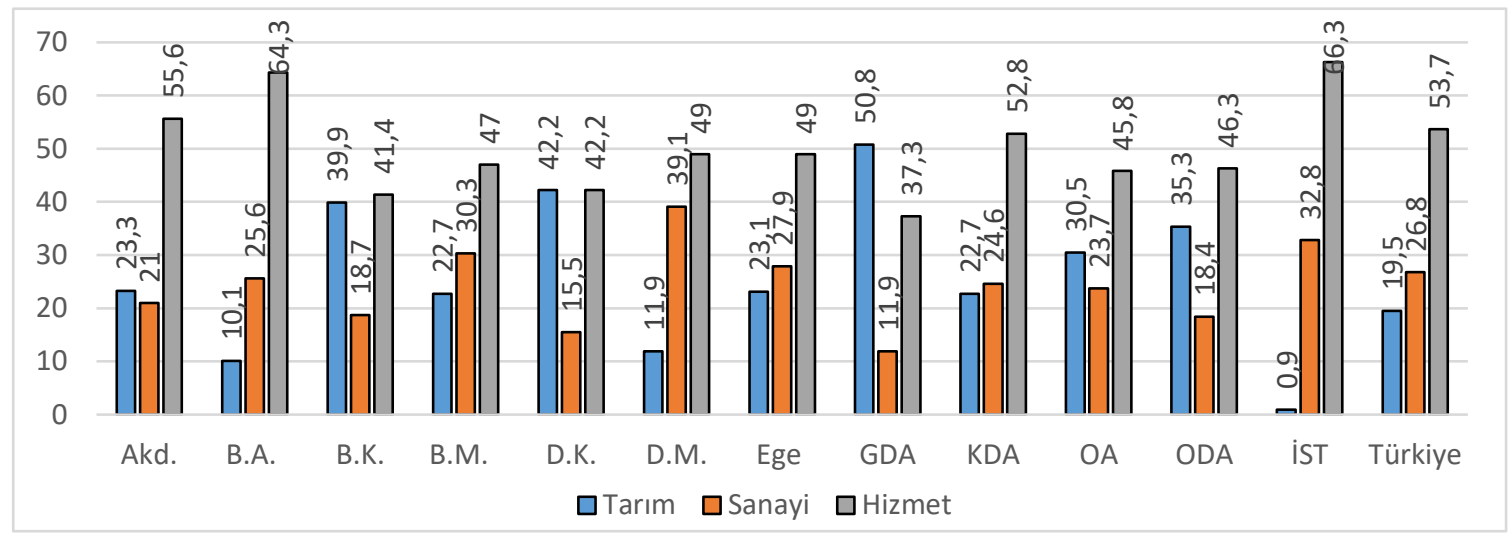

Kaynak: TÜiK Bölgesel İstatistikler 2016

Türkiye'nin genel tablosu istihdam edilenlerin \%53,7'si hizmet, \%26,8'si sanayi, \%19,5'i tarım sektöründedir. Bölgelerin faaliyet kollarına göre istidam oranları incelendiğinde Ortadoğu Anadolu, Orta Anadolu, Güneydoğu Anadolu, Doğu Karadeniz, Batı Karadeniz, Akdeniz bölgeleri Türkiye'nin tablosundan farklılık göstermektedir. Bu bölgelerin tarım sektöründeki istihdam oranı sanayi sektörü istihdam oranından 
yüksektir. Sanayi sektöründe istihdam oranı en yüksek bölge Doğu Marmara bölgesidir. Bu bölgeyi Türkiye ortalamasının üstünde olan İstanbul, Batı Marmara ve Ege bölgeleri takip etmektedir. Batı Anadolu, Orta Anadolu ve Kuzeydoğu Anadolu Bölgeleri Türkiye oranının bir iki puan altında olan bölgelerdir. Sanayi sektöründe en düşük istihdam oranı Güneydoğu Anadolu bölgesindedir. Bu bölgeyi Doğu Karadeniz, Ortadoğu Anadolu ve Batı Karadeniz bölgeleri takip etmektedir.

\section{Yöntem ve Bulgular}

\subsection{Bölgelerinin Rekabet Gücünü Belirlemeye Çok Ölçütlü Bakış}

Çoğu zaman tek bir ölçüte göre değerlendirme ya da seçim yapmak mümkün değildir. Bir ölçüte göre en iyi olan seçenek başka bir ölçüt için tercih edilmeyen bir seçenek olabilir. Bu durumda karşımıza çıkan problem "çok ölçütlü karar verme problemi" olarak adlandırılır. İlgili problemlerde karar tek faktörün değil, çok sayıda faktörün etkisi ile oluşmakta, dolayısıyla karmaşık bir yapı göstermektedir. Bu nedenle ilgili model, sadece tek değişkene veya tek ölçüte göre değil, çok sayıda faktöre ve bunların ortaklaşa etkilerine göre tanımlanmalıdır. Çalışmada Türkiye'nin iBBS Düzey 1'e göre sınıflandırılmış bölgelerinin rekabet gücünü belli ölçütler temelinde ele alarak çok ölçütlü karar verme tekniği olan ELECTRE-3 (ELimination Et Choix Traduisant la REalite) ile Türkiye'nin Düzey 1'e göre sınıflandırılmış bölgelerin sıralanması amaçlanmıştır.

\subsection{ELECTRE Yöntemi}

ELECTRE yöntemi 1960 'ı yılların sonunda Roy tarafından ortaya atılmıştır. Bu yöntemde, seçenekler tercih sıralamasına göre birbirleriyle kıyaslanarak seçim yapılması temeline oturtulmuştur. Sıralama ilişkisi kısaca çiftli karşılaştırmayla kurulmaktadır. Seçim için tüm seçenekler birbirleriyle kıyaslanmalıdır. Yöntemin adımları (Yaralıoğlu, 2006);

1. Adım: Karar matrisinin (A) oluşturulması

2. Adım: Ölçütlerin ağırlıklarının hesaplanması

3. Adım: Normalleştirilmiş karar matrisinin hesaplanması

4. Adım: Ağırlıklı normalleştirilmiş değerlerin hesaplanması

5. Adım: Uyum $\left(C_{k l}\right)$ ve uyumsuzluk $\left(D_{k l}\right)$ kümelerinin belirlenmesi

6. Adım: Uyum (C) ve uyumsuzluk matrislerinin (D) oluşturulması

7. Adım: Uyum baskınlık (F) ve uyumsuzluk baskınlık (G) matrislerinin oluşturulması

8. Adım: Birleşik baskınlık matrisinin (E) oluşturulması

9. Adım: Karar noktalarının önem sırasının belirlenmesi

E matrisinin satır ve sütunları karar noktalarını gösterir. Örneğin; E matrisi

$$
E=\left[\begin{array}{ccc}
- & 0 & 0 \\
1 & - & 0 \\
1 & 1 & -
\end{array}\right]
$$

şeklinde olsun. $e_{21}=1, e_{31}=1$ ve $e_{32}=1$ değerleri; 2 . karar noktasının 1. karar noktasına 3. karar noktasının 1. karar noktasına ve 3. karar noktasının da 2. karar noktasına mutlak üstünlüğünü gösterir. Bu durumda karar noktaları $A_{i}(i=1,2, \ldots, m)$ sembolüyle ifade edilirse, karar noktalarının önem sırası $A_{3}, A_{2}$ ve $A_{1}$ şeklinde oluşacaktır. 


\subsection{ELECTRE III Model ve Sonuçları}

Çalışmada bölgelerin rekabet gücü açısından sıralanması amacıyla bir model kurulmuştur. Model, bölgelerin iş yaratma potansiyeline ilişkin ölçütleri içermektedir. Bölüm 4.1'de detayı anlatılan ölçütler Tüik bölgesel istatistik veriler kullanılarak hesaplanmıştır. Ölçütler sırasıyla;

- Ölçüt 1: İmalat Sanayide İşgücü Verimliliği

- Ölçüt 2: AR-GE İnsan Gücü

- Ölçüt 3: Sanayideki İhracat Oranı

- Ölçüt 4: Girişimci Sayısı

Tablo 1'de kullanılan verileri gösteren performans matrisi verilmiştir.

Tablo 1. Performans Matrisi

\begin{tabular}{|l|l|c|c|c|c|}
\hline Alternatifler & Bölgeler & Ölçüt 1 & Ölçüt 2 & Ölçüt 3 & Ölçüt 4 \\
\hline Alternatif 1 & TR1(iST.) & 89654,06 & 11,16 & 0,97 & 883372 \\
\hline Alternatif 2 & TR2 (Batı Marmara) & 79462,57 & 5,69 & 0,95 & 177144 \\
\hline Alternatif 3 & TR3 (Ege) & 78266,35 & 7,01 & 0,86 & 533844 \\
\hline Alternatif 4 & TR4 (Doğu Marmara) & 91766,01 & 12,01 & 0,98 & 340743 \\
\hline Alternatif 5 & TR5 (Batı Anadolu) & 90860,25 & 20,99 & 0,9 & 370909 \\
\hline Alternatif 6 & TR6 (Akdeniz) & 69652,74 & 4,69 & 0,7 & 464978 \\
\hline Alternatif 7 & TR7 (Orta Anadolu) & 70552,27 & 7,48 & 0,94 & 157349 \\
\hline Alternatif 8 & TR8 (Batı Karadeniz) & 55724,35 & 5,50 & 0,92 & 184024 \\
\hline Alternatif 9 & TR9 (Doğu Karadeniz) & 64198,72 & 6,57 & 0,42 & 112580 \\
\hline Alternatif 10 & TRA (Kuzeydoğu Anadolu) & 49627,45 & 8,70 & 0,96 & 62597 \\
\hline Alternatif 11 & TRB (Ortadoğu Anadolu) & 55511,86 & 6,60 & 0,8 & 113931 \\
\hline Alternatif 12 & TRC (Güneydoğu Anadolu) & 68330,187 & 3,99 & 0,95 & 251050 \\
\hline
\end{tabular}

Tablo 1 Türkiye'de iBBS Düzey 1'e göre sınıflandırılmış bölgeleri modelde karşılaştırılacak alternatifleri göstermektedir. Satırlarda alternatif Düzey 1'e göre sınıflandırılmış bölgeler, sütunlarda her bir ölçütün ilgili bölge için verisi yer almaktadır. Örneğin, alternatif 6 olarak kodlanan Akdeniz Bölgesi için İmalat sanayisinde iş gücü verimliliği (bölgenin sanayi üretimi/bölgenin sanayide istihdam edilenlerin sayısı) 69.653,74'dir. Ölçüt 2 değeri (AR-GE İnsan gücü) 4,69, ölçüt 3 (Sanayideki ihracat oranı) 0,7 ve ölçüt 4 (girişimci sayısı) 464.978 olarak TÜik veri tabanından alınarak modelde kullanılmıştır. 
Tablo 2. Model 1'deki Ölçütler ve Amaca Etkisi

\begin{tabular}{|r|l|l|}
\hline Ölçüt No & Ölçütler & Amaca Etkisi \\
\hline Ölçüt 1 & İmalat Sanayide İşgücü Verimliliği & Artan \\
\hline Ölçüt 2 & Ar-Ge İnsan Gücü & Artan \\
\hline Ölçüt 3 & Sanayideki İhracat Oranı & Artan \\
\hline Ölçüt 4 & Girişimci Sayısı & Artan \\
\hline
\end{tabular}

Tablo 2'de modelde kullanılan ölçütler ve modelin amaca olan etkileri gösterilmiştir. Ölçütlerin çalışmanın amacı olan işsizliği düşürmesine ya da istihdam artışına olan etkisi dikkate alınmıştır. Türkiye'de bölgeleri Tablo 3'teki ölçütlere göre kıyaslamak hangi bölgenin rekabet gücü açısından üstün olduğunu söylemek mümkün değildir. Dolayısıyla bu bir "çok ölçütlü karar problemi”dir.

Modelde karar vericilerin ölçüt ağırlıklarını değiştirmesi bölgelerin sırasını etkilemektedir. Bu çalışmada ölçütlere farklı ağırlıklar verilerek dört senaryo türetilmiş̧ir. Her bir senaryoda karar verici farklı ölçütlere farklı ağırlıklar verdiği varsayılmıştır. Senaryolara ilişkin karar vericilerin ölçütlere verdikleri ağılıklar Tablo 3'te gösterilmiştir.

Tablo 3. Dört Karar Verici İçin Ölçütlerin Ağırlığı

\begin{tabular}{|l|c|c|c|c|}
\hline Karar vericiler & Ölçüt 1 & Ölçüt 2 & Ölçüt 3 & Ölçüt 4 \\
\hline Karar verici 1 & $\% 25$ & $\% 25$ & $\% 25$ & $\% 25$ \\
\hline Karar verici 2 & $\% 25$ & $\% 30$ & $\% 20$ & $\% 25$ \\
\hline Karar verici 3 & $\% 40$ & $\% 20$ & $\% 20$ & $\% 20$ \\
\hline Karar verici 4 & $\% 20$ & $\% 40$ & $\% 20$ & $\% 20$ \\
\hline
\end{tabular}

Karar vericileri politika yapıcı olarak düşünürsek, Tablo 3'e göre Karar verici 1 dört ölçeğe eşit ağırlık vermiştir. Karar verici 2 bölgedeki istihdamda yer alan AR-GE insan gücünün istihdamdaki oranının bölgenin rekabet gücünü önemli ölçüde etkileyeceğini düşündüğünü ve bu sebeple ölçüt 2'ye diğerlerine göre fazla ağırlık vermiştir. Karar verici 3 bölgelerdeki imalat sanayisinin işgücü verimliliğinin bölgenin rekabet gücünü arttırmada diğer ölçütlere göre daha fazla etkili olduğunu düşünmektedir. Karar verici 4, karar verici 2 ile benzer düşünmekle birlikte AR-GE insan gücünün istihdamdaki oranının bölgenin rekabet gücünü önemli ölçüde etkileyeceğini diğer ölçütlerin eşit ağırlıklı etkilediğini düşünmektedir. Dört karar vericinin ELECTRE III ile bulunmuş bölge sıralamaları Tablo 4'te verilmiştir.

Dört karar verici için işsizliği düşürmede iş yaratma potansiyeline sahip bölgelerin rekabet gücüne göre ilk sırada İstanbul yer almaktadır. İkinci sırada Doğu Marmara ve Batı Anadolu bölgeleri yer alırken üçüncü sırada Ege bölgesi, dördüncü sırada Akdeniz ve Batı Anadolu bölgeleri yer almaktadır. Dördüncü sıradan sonra bölgelerin sıralanması karar vericilere göre değişmektedir. İstanbul bölgesi için dört ölçüte ilişkin veriler diğer bölgelerle kıyaslandığında daha yüksek olduğundan İstanbul'un dört karar verici için de birinci sırada çıkması olağandır. Doğu Marmara ve Batı Anadolu bölgeleri modele göre İstanbul'dan sonra ikinci sırada yer almaktadır. İmalata sanayisinde işgücü verimliliği, AR-GE insan gücü, sanayideki ihracat oranı ve girişimci sayısı bakımından ilgili iki bölge model tarafından aynı sınıfta ve ikinci sırada olarak değerlendirilmiştir. 
Tablo 4. Dört Farklı Karar Verici İçin Bölgelerin Sıralamaları

\begin{tabular}{|l|c|c|c|c|}
\hline Bölgeler & $\begin{array}{l}\text { Karar verici } \\
\text { 1'ye göre } \\
\text { sıralama }\end{array}$ & $\begin{array}{l}\text { Karar verici } \\
\text { 2'ye göre } \\
\text { sıralama }\end{array}$ & $\begin{array}{l}\text { Karar verici 3'e } \\
\text { göre sıralama }\end{array}$ & $\begin{array}{l}\text { Karar verici 4'e } \\
\text { göre sıralama }\end{array}$ \\
\hline TR1 (iST.) & $\mathbf{1}$ & $\mathbf{1}$ & $\mathbf{1}$ & $\mathbf{1}$ \\
\hline TR2 (Batı Marmara) & $\mathbf{4}$ & $\mathbf{4}$ & $\mathbf{5}$ & $\mathbf{4}$ \\
\hline TR3 (Ege) & $\mathbf{3}$ & $\mathbf{3}$ & $\mathbf{3}$ & $\mathbf{3}$ \\
\hline TR4 (Doğu Marmara) & $\mathbf{2}$ & $\mathbf{2}$ & $\mathbf{2}$ & $\mathbf{2}$ \\
\hline TR5 (Batı Anadolu) & $\mathbf{2}$ & $\mathbf{2}$ & $\mathbf{2}$ & $\mathbf{2}$ \\
\hline TR6 (Akdeniz) & $\mathbf{4}$ & $\mathbf{4}$ & $\mathbf{4}$ & $\mathbf{4}$ \\
\hline TR7 (Orta Anadolu) & $\mathbf{5}$ & $\mathbf{4}$ & $\mathbf{6}$ & $\mathbf{5}$ \\
\hline TR8 (Batı Karadeniz) & $\mathbf{6}$ & $\mathbf{5}$ & $\mathbf{7}$ & $\mathbf{6}$ \\
\hline TR9 (Doğu Karadeniz) & $\mathbf{7}$ & $\mathbf{6}$ & $\mathbf{8}$ & $\mathbf{7}$ \\
\hline TRA (Kuzeydoğu Anadolu) & $\mathbf{7}$ & $\mathbf{5}$ & $\mathbf{8}$ & $\mathbf{5}$ \\
\hline TRB (Ortadoğu Anadolu) & $\mathbf{8}$ & $\mathbf{7}$ & $\mathbf{9}$ & $\mathbf{8}$ \\
\hline TRC (Güneydoğu Anadolu) & $\mathbf{9}$ & $\mathbf{8}$ & $\mathbf{1 0}$ & $\mathbf{9}$ \\
\hline
\end{tabular}

İmalat sanayisindeki işgücü verimliliğine daha çok ağırlık (\%40) veren Karar verici 3’e göre diğer Karar vericilerden farklı olarak Batı Marmara bölgesi dördüncü sıradan beşinci sıraya düşmüştür. Benzer şekilde Orta Anadolu, Batı Karadeniz, Doğu Karadeniz, Kuzeydoğu Anadolu, Ortadoğu Anadolu ve Güneydoğu Anadolu bölgelerinin de bir ya da iki puan alt sıraya düştüğü görülmektedir.

Ölçütlere eşit ağırlık veren karar verici 1'in düşüncesi temel olarak alınırsa, AR-GE insan gücüne ağılık veren karar verici 2'nin sıralaması farklılık göstermektedir. Dördüncü sıradan sonra her bölgenin sıralaması bir üst sıraya çıkmıştır. AR-GE insan gücünün istihdamdaki oranı bu bölgelerin sıralamasını iyileştirmektedir. Karar verici 3'e göre ilk dört bölge aynı sıralamaya sahipken beşinci sıralamadan sonra bölgeler sıralamaları farklılık göstererek alt sıralara kaymıştır.

\section{Sonuç}

Ülkeler küreselleşme ve teknolojik gelişmenin ekonomik koşullar üzerindeki olumsuz etkisi sonucu ortaya çıkan işsizlik sorununa yeni istihdam alanları yaratmak amacıyla politika geliştirmeye odaklanmıştır. Rekabet gücü yüksek olan ekonomilerin yeni istihdam alanları yaratabilme becerileri daha yüksektir. Rekabet gücünün geliştirilmesinde bölgelerin birer uygulama alanı olması, bölgelerin rekabet gücüne yönelik politikaların önemini daha da ön plana çıkarmaktadır. Bu bağlamda bölgeler hem makro anlamda ülkenin rekabet gücünü etkileyen hem de mikro anlamda firmaların rekabet gücü tarafından etkilenen ve etkileyen önemli konuma sahiptir. Avrupa komisyonu bölgesel rekabet edilebilirliği "yüksek ve sürdürülebilir faktör gelirine sahip olma ve faktör istihdam düzeyi yaratabilme becerisi olarak tanımlamaktadır. Çalışmada bölgenin rekabet gücü işsizliği azaltan ya da istihdamı arttıran imalat sanayisinde verimlilik, AR-GE insan gücü sayısı, sanayinin ihracat oranı ve girişimci sayıları olarak dört adet ölçüt (değişken) dikkate alınmış ve Düzey 1'e göre sınıflandırılmış bölgeler rekabet gücüne göre sıralanmıştır. Modelde dikkate alınan ölçütler temelinde, karar vericilerin bölgenin rekabet gücünü arttırmada etkili olan ölçütlere verdiği önem (ağırık) ne olursa olsun ilk dört bölgenin sırası değişmemektedir. Bu bölgeler sırasıyla; i̇stanbul, Doğu Marmara, Batı Anadolu, Ege, Akdeniz ve Batı Marmara bölgesidir. Bu bölgelerin nispi olarak sanayi sektörlerinin daha gelişmiş olması, bölgenin sanayi yoğun nitelik taşıması ve diğer sektörleri beslemesi bu bölgelerin daha fazla 
istihdam yaratma ya da işsizliği düşürme potansiyeline sahip olduğu anlamına gelebilir. Karar verici 2 ile karar verici 4,'ün AR-Ge çalışan sayısının bölgenin rekabet gücünü arttırmada daha etkili olduğu düşündüğünü varsaydığımızda diğer bölgelerin sıralaması değişmektedir. AR-GE insan gücünün istihdamdaki oranı bu bölgelerin sıralamasını iyileştirmektedir. Kuzeydoğu Anadolu bölgesi 7. ve 8. sıradan 5. sıraya yerleşmektedir. Ar-Ge çalışan sayısının artmasının bölgenin rekabet gücünü arttıracağını söylemek yanlış olmayacaktır. Mevcut bölgesel politikaların küreselleşme ve teknolojideki gelişim sonucu oluşan koşullara uyum sağlamadaki yetersizliği bölgelerin beklenilen hedeflere ulaşabilmek için yeni bir bakış açısıyla değerlendirilmesini gerektirir. Bu çalışma ile ele alınan ölçütler temelinde bölgelerin farklılıkları ortaya konmuş ve dört farklı Karar verici açısından sıralanmıştır. Bölgesel politikaları geliştiren Karar vericilerin ilgili sıralamaları ve ölçütleri dikkate alarak politikalar geliştirmesi önerilebilir.

\section{Kaynaklar}

Albayrak, A. N., \& Erkut, G. (2010). Türkiye'de bölgesel rekabet gücü analizi. Megaron, 5(3), 137-148.

Akyelken, N. (2015). Infrastructure development and employment: The case of Turkey. Regional Studies, 49(8), 13601373.

Ayaş, N. (2002). Bölgesel rekabet gücünün geliştirilmesinde verimliliğin rolü. Muğla Üniversitesi Sosyal Bilimler Enstitüsü Dergisi, 9, 1-14.

Aydın, C. (2017). Türkiye'de bölgesel enflasyonun bölgesel işsizlik ve büyüme üzerine etkisi: Panel yumuşak geçişli regresyon yaklaşımından yeni kanıtlar. Yönetim ve Ekonomi Araştırmaları Dergisi, (15)3, 114-131.

Beceren, E. (2004). Bölgesel rekabet gücü. Süleyman Demirel Üniversitesi iktisadi ve Idari Bilimler Fakültesi, 9(2), 279302.

Cai, F., Wang, D., \& Du, Y. (2002). Regional dizparity and economic growth in China : The impact of labor market distorions. China Economic Review, 13(2), 197-212.

Camagni, R. (2002). On The concept of territorial competitiviness: Sound or misleading? Urban Studies, 38(9), 10011014.

Commission of the European Communities (CEC), (1999). Turkey 1999 regular report. http://ec.europa.eu/enlargement/archives/pdf/key_documents/1999/package/sec_142 6_final_regular_report_tr_en.pdf (07.10.2018)

Dabson, B. (2005). Regional competitiveness, Innovation and entrepreneurship, economic development and the University of Missouri-Columbia, Framing the Debate, Working Paper.

Enflo, K., \& Roses, J. R. (2015). Coping with regional inequality in Sweden: Structural change migrations and policy 18602000. The Economic History Review, 68(1), 191-217.

Gerreffi, G. (1999). International trade and Industrial upgrading in the apparel commodity chain. Journal of International Economics, 48(1), 37-70.

Güney, A. (2009). İ̧̧sizlik nedenleri, sonuçları ve mücadele yöntemleri. Kamu-Iş̧ Dergisi, 10(4), 135-159.

Huovari, J., Kangazharharju, A., \& Alanen, A. (2001). Constructing an index for regional competitiveness. Pellervo Economic Research Institute: PTT.

Kara, M. (2008). Bölgesel rekabet edilebilirlik kavramı ve bölgesel kalkınma politikalarına yansımaları. DPT Uzmanlık Tezi, Yayın No: DPT:2774.

Kerimoğlu, E., \& Sözer, S. (2017). Türkiye'de bölgesel rekabet ve rekabetçi bölgeler. Planlama, 27(3), 236-253.

Kitson, M., Martin, R., \& Tyler, P. (2004). Regional competitiveness: An elusive yet key concept? Regional Studies, 38(9), 991-999.

Lee, Y. J., \& Hyoungso, Z. (1998). Urbanisation and regional productivity in Korean manufacturing. Urban Studies, 35(11), 2085-2099.

Lechman, E., \& Kaur, H. (2015). Economic growth and female labor force participation-verifying the $U$ feminization hypothesis. New Evidence for 163 countries over the period 1990-2012. Economics and Sociology, (1), 246-257.

Kaldor, N. (1975). Economic growth and the Verdoorn Law: A comment on Mr Rowthorn's article. The Economic Journal, $85,891-896$ 
Nordas, H. K., \& Kim, Y. (2013). The role of services for competitiveness in manufacturing. OECD Trade Policy Papers, http://dx.doi.org/10.1787/5k484xb7cx6b-en, (4.02.2018).

Öztürk, S. (2018). Türkiye'de işgücüne katılımda bölgesel farklılıklar. Sosyoekonomi, 26(35), 153-168.

Özdemir, S., Ersöz, H. Y., \& Sarıoğlu, H. İ. (2006). İşsizlik sorunun çözümün kobilerin desteklenmesi. İstanbul: İstanbul Ticaret Odası, Yayın No: 2006: 45.

Parlaktuna, í., \& Sarıçiçek, í. (2010). Türkiye'de bölgelerin kadın işgücünü arttırma konusunda potansiyel güçlerine göre sıralanması: Çok ölçütlü karar verme modeli uygulaması. İktisat İşletme ve Finans, 25(294), 35-65.

TÜiK 2014 Türkiye İstatistik Kurumu, http://www.tuik.gov.tr 20/01/2018

TÜiK 2015 Türkiye İstatistik Kurumu, http://www.tuik.gov.tr 20/01/2018

TÜiK 2016 Türkiye İstatistik Kurumu, http://www.tuik.gov.tr 20/01/2018

Yaralığlu, K. (2006). Electre yöntemi. Dokuz Eylül Üniversitesi Yüksek Lisans Tezi, İzmir.

Yüceol, H. M. (2007). Türkiye'de bölgesel işgücü hareketleri, işsizlik ve ekonomik kalkınma. İş Güç Endüstri ilişsiler ve İnsan Kaynakları Dergisi, 9(1) ISSN: 1303-2860.

Webster, D., \& Muller, L. (2000). Urban competitiveness assessment in developing country urban regions: The road foward. The World Bank, Washington D.C. 
This Page Intentionally Left Blank 